Zabytkoznawstwo i Konserwatorstwo XLIV, Toruń 2013

Ewa Doleżyńska-Sewerniak

UKW, Bydgoszcz

\title{
Kolorystyka fasad zabytkowych budynków z przełomu XIX i XX wieku Olsztyna i małych miast Warmii i Mazur
}

\section{Wstęp}

$\int_{Z}$ ednym z bardziej istotnych problemów konserwatorskich zabytków architektury jest przywracanie i projektowanie kolorystyki ich fasad. Z etapem tym nierozerwanie związane są zagadnienia odtwarzania faktury tynków. Ta faza prac jest finalna w całokształcie złożonych działań konserwatorsko-restauratorskich historycznych budynków i zarazem najbardziej widoczna. Ma wpływ na wygląd samego zabytku, ale także pierzei czy placu miasta.

Problematyka kolorystyki fasad poruszana była wielokrotnie przez licznych badaczy ${ }^{1}$. Zagadnienie to nie doczekało się jednak nadal kompleksowego potraktowania. Brak jest także opracowań cząstkowych, np. poje-

1 M.in. M. Arszyński, O problemach kolorystyki fasad, „Zeszyty Naukowe Uniwersytetu Mikołaja Kopernika”, Toruń 1966, s. 151-166; materiały konferencji Kolorystyka i faktura w architekturze, „Architectus” 2000, nr 1 (7); J. Miśkowiec, Kolorystyka elewacii uybranych kamienic mieszrzańskich w Toruniu i ich problematyka konserwatorska, [w:] Studenci o konserwacji, t. 2, Materiały II Ogólnopolskiej Konferencji Naukowej Studentów Konserwacji Zabytków, red. T. Korzeniowski, Toruń 2000, s. 85-98; Brzezowski, O kolorystyce architektury w okresie nowo:sytnym, [w:] Monumenta conservanda sunt. Ksiega ofiarowana Profesorowi Edmundowi Małachowiczowi w siedemdziesiata piata rocznice urodzin. Wrocław 2001; Kolorystyka zabytkonych elewacï od średnioniecza do wspótczesności. Historia i konserwacja, red. K. Guttmejer, Materiały międzyna- 
dynczych budynków, zespołów urbanistycznych poszczególnych miast czy większego regionu itp. Pomimo iż w ostatnim czasie ukazały się ważne i wartościowe publikacje dotykające tego tematu, niewiele pisze się również o architekturze XIX-wiecznej, a przecież budynki z tego okresu zachowane są bardzo licznie.

W ostatnich latach dzięki środkom unijnym przeprowadza się wiele remontów obiektów zabytkowych. Coraz częściej renowacje poprzedzaja badania konserwatorskie, których celem jest rozpoznanie techniki i technologii opracowania lica budynku. Dzięki dość restrykcyjnym działaniom urzędów konserwatorskich na terenie województwa warmińsko-mazurskiego systematycznie prowadzone są badania stratygraficzne narzutów tynkarskich i wymalowań elewacji zabytków tego regionu. Często towarzyszą im także analizy składu chemicznego wypraw tynkarskich i warstw barwnych, pozwalające na rozróżnienie tynków „nowych” od historycznych oraz na rozpoznanie technologii pierwotnych nawarstwień. Badania te ułatwiaja zaprojektowanie metod i środków konserwatorskich, niezbędnych do odnowienia i przywracania pierwotnego charakteru zabytkowym budynkom. Ich rezultaty pozwalaja na zaobserwowanie charakterystycznych tendencji w opracowaniu barwnym obiektów architektonicznych z przełomu XIX i XX wieku na tym terenie.

Ze względu na fakt, że wiele obiektów powstałych na przełomie XIX i XX wieku poddawanych jest remontom przyczyniającym się do niszczenia historycznych warstw oraz na prowadzone regularnie badania kolorystyki elewacji zabytków terenu obecnego województwa warmińsko-mazurskiego, w artykule omówiono wyniki tych badań. Dotyczy to Olsztyna i mniejszych miejscowości Warmii i Mazur, wśród których były: Lidzbark Warmiński, Mragowo, Olsztynek, Kętrzyn, Iława, Górowo Iławeckie, Biskupiec, Jeziorany, Bartoszyce i Ostróda. Badania prowadziła autorka tego artykułu w latach 2007-2011 na zlecenia inwestorów prac remontowych, Wojewódzkiego Urzędu Ochrony Zabytków, a także Miejskiego Konserwatora Zabytków w Olsztynie.

rodowej konferencji z okazji 30-lecia wpisu Starego Miasta w Warszawie na Listę Światowego Dziedzictwa UNESCO, Warszawa 22-24 września 2010. 
Badane budynki to obiekty reprezentacyjne dla tego okresu i regionu, ponieważ są usytuowane w obrębie głównych ulic centrów miast tego województwa. Rzadziej analizowano zabytki oddalone od historycznego starego miasta. Do tych ostatnich należały np. powstały jako podmiejska rezydencja budynek obecnej Wojewódzkiej Biblioteki Publicznej, znajdującej się przy ul. 1 Maja 5 w Olsztynie, czy dawna willa miejska przy ul. Sienkiewicza $10 \mathrm{w}$ Iławie oraz prywatna willa przy ul. Mickiewicza $12 \mathrm{w}$ Biskupcu. Nie są znani projektanci tych budynków, choć wiadomo, że w tym czasie w Olsztynie czynni byli architekci. W 1914 roku działało ich ośmiu, w roku 1938 jedenastu². Znani są natomiast pierwsi właściciele niektórych kamienic. Byli to kupcy, brukarze, mistrzowie budowlani, kolejarze, spółdzielnie mieszkaniowe itp.

Nie zachowały się, niestety, projekty kolorystyczne analizowanych budynków, ani szczegółowe informacje o ich renowacjach, choć na podstawie ich oględzin można stwierdzić, że były one liczne. W poprzednich dziesięcioleciach historyczne tynki niszczono w trakcie remontów, nie wykonując dokumentacji fotograficznych i opisowych przeprowadzanych zabiegów. Dopiero prowadzone w ostatnich latach konserwacje poprzedzaly badania stratygraficzne i ich dokumentacja.

Dużą grupę analizowanych obiektów stanowią kilkukondygnacyjne (trójkondygnacyjne i czterokondygnacyjne) kamienice czynszowe, ale sa wśród nich także jednopiętrowe budynki wolnostojące (jak np. budynek przy ul. Grunwaldzkiej 33 w Olsztynie i ul. Konstytucji 3 Maja 5 w Lidzbarku Warmińskim), a także użyteczności publicznej - ratusze, szkoły, siedziba rejencji w Olsztynie $\mathrm{i}$ in.

Reprezentują one typowe dla epoki style architektoniczne. Większość z nich ma elewacje o wyraźnych cechach historyzmu - głównie klasycyzujące. Do nich można zaliczyć np. kamienice przy ul. Orkana 5 w Olsztynie, ul. Wyszyńskiego 17, 18 i 20 oraz ul. Kopernika 2 i 4 w Lidzbarku Warmińskim, przy ul. Żeromskiego 1, 3, 5 i 9, Królewieckiej 7 i 49 i Wojska Polskiego $1 \mathrm{w}$ Mragowie, a także przy ul. Powstańców Warszawy 9 w Kętrzynie. Wśród nich dużą grupę stanowią również budynki bezstylowe, np. przy ul. Hożej 11 i 15, Ratuszowej 2, Wysokiej Bramy 9, Mickie-

2 A. Wakar, Olsztyn 1353-1945, Olsztyn 1971, s. 235, 280. 
wicza 15 w Lidzbarku Warmińskim, Grunwaldzkiej 33 w Olsztynie, a także Daszyńskiego 6 w Kętrzynie i Żeromskiego 2 w Mragowie. Olsztyńską secesję reprezentują natomiast np. obiekty przy ul. Knosały 7 i Zientary Malewskiej 3 w Olsztynie.

Pod względem opracowania lica spośród przebadanych są fasady w całości tynkowane i pokryte wymalowaniami oraz elewacje wykonane z cegły licówki z tynkowanymi detalami, np. gzymsami, obramieniami okiennymi i sztukateriami oraz barwionymi lub pomalowanymi spoinami (np. przy ul. Linki 5 w Olsztynie, Roosevelta 13, Warszawskiej 53 w Mragowie i ul. Sikorskiego 19 w Kętrzynie). Analizowano także budynki częściowo tynkowane z ceglanymi gzymsami i z barwnym spoinowaniem (np. przy pl. Bema 3, ul. Żeromskiego 39 w Olsztynie, czy ul. Roosevelta 19 w Mragowie). Do tych ostatnich należą również obiekty koszarowe np. przy ul. Jagiellońskiej 50 w Olsztynie.

Wiele $\mathrm{z}$ nich ma nieznacznie zmienioną formę. Przykładem takiego budynku jest kamienica przy ul. Żeromskiego 39 w Olsztynie, której boniowanie parteru zostało otynkowane na gładko (fot. 1-3). Przekształcenia dotyczą także dolnych kondygnacji elewacji frontowych, gdzie na potrzeby usługowe wybijano nowe otwory drzwiowe i okienne. Historyczne podziały burzono również poprzez wstawianie witryn sklepowych. Przekształcenia dotyczyły także obramień okiennych i drzwiowych, które poszerzano lub wydłużano w celu wstawienia nowego „bardziej funkcjonalnego”, np. wykonanego z PCV okna lub drzwi. W niektórych z nich przebudowywano dachy i nadbudowywano dodatkowe piętra, wymieniano ceramiczną dachówkę na blacho-dachówkę itp. Inne dość drastycznie przebudowano, dlatego przywracanie im. pierwotnej barwy w ich obecnym, nowym kształcie mogłoby być nieuzasadnione.

Obiekty poddane badaniom powstały między 2. połową XIX wieku a latami 20. XX wieku. Był to czas intensywnej rozbudowy Olsztyna. Do ostatniego trzydziestolecia XIX wieku był on miastem małym i biednym. W roku 1864 liczył 4793 mieszkańców, a w roku 1895 już 21554. Rozwój ten miał miejsce po 1868 roku, kiedy w mieście wybudowano linię kolejo$w_{a}^{3}$. Do XIX wieku obszar zwartej zabudowy nie rozszerzał się. U progu

3 Ibidem, s. 165. 
tego stulecia rozpadły się mury obronne, a miasto zaczęło rozrastać się poza mury miejskie. Zwiększająca się liczba mieszkańców zainicjowała intensywny ruch budowlany. W okresie 1865-1875 w Olsztynie powstało 117 budynków. Dalszy rozwój węzła komunikacyjnego przyczynił się do uzyskania przez niego połączeń kolejowych z mniejszymi miejscowościami, np. Orneta, Szczytnem, Olsztynkiem i in. Na dawnych jego peryferiach zaczęły powstawać budynki użyteczności publicznej, jak: gimnazjum miejskie, budynek sądu, starostwa powiatowego, gmach poczty, szkoła podstawowa i in. W latach 1885-1890 zbudowano w Olsztynie 252 budynki. W 1890 roku zakończono prace przy węźle kolejowym, ale kontynuowano budownictwo czynszowe. Olsztyn w 1890 roku zgazyfikowano, w 1899 otrzymał kanalizację i wodociagi, a w roku 1907 elektryczność i komunikację tramwajowa. Na przełomie XIX i XX wieku w mieście zaczęto budować w stylu secesyjnym ${ }^{4}$.

Rozwój Olsztyna, powstanie nowych dzielnic, związany był również z rozwojem administracji, garnizonu wojskowego oraz przemysłu, głównie spożywczego, przetwórczego i drzewnego. Dzięki dynamicznemu rozwojowi stał się on drugim co do wielkości miastem w Prusach Wschodnich. W 1903 roku w mieszkało już w nim ponad 25000 mieszkańców. Od 1905 roku był siedziba rejencji, odpowiednika województwa. Pod koniec XIX wieku stał się stolicą regionu, największym miastem Warmii i jednocześnie największym miastem Pojezierza Mazurskiego ${ }^{5}$.

Sieć ulic i parcel budowlanych wewnątrz Starego Miasta Olsztyna zachowała się bez większych zmian do II wojny światowej. Same kamieniczki mieszczańskie w tym czasie przebudowywano, co przyczyniło się do utracenia przez nie wielu ze swych wartości zabytkowych. W roku 1890 zakończono prace przy węźle kolejowym. Spowodowało to krach finansowy miasta. Okres I wojny światowej i kryzys, jaki nastapił po tym wydarzeniu, również zahamowały intensywny jego rozwój. Czas ponownego wzmożenia ruchu budowlanego w Olsztynie przypadł na ostatnie lata przed II wojna światowa. Podczas trwania wojny 36\% miasta uległa zniszczeniu ${ }^{6}$.

4 St. Archemczyk, Drieje Miasta Olsztyn, Wrocław 2004, s. 104-110; A. Wakar, op. cit., s. 199.

5 St. Archemczyk, op. cit., s. 110-120; A. Wakar, op. cit., s. 165, 212.

6 St. Archemczyk, op. cit., s. 163; A. Wakar, op. cit., s. 201, 208. 
Wiele mniejszych miast tego rejonu swą świetność i rozwój zawdzięczaja powstaniu połączeń kolejowych z innymi miastami i Olsztynem (m.in. Orneta, Olsztynek, Biskupiec, Ostróda, Miłomłyn, Mragowo i Kętrzyn), a także przemianom cywilizacyjnym, jakie miały miejsce w końcu XIX wieku, do których należy zaliczyć elektryfikację tego regionu na początku XX w., rozwój sieci kanalizacyjnych i wodociagowych, rozwój przemysłu (np. browarniczego w Biskupcu) i handlu (np. drewnem w Miłomłynie) ${ }^{7}$.

Duża grupa zespołów staromiejskich została spalona w 1945 roku po zajęciu Prus Wschodnich przez Armię Czerwoną. Olsztyn odbudowano, w innych ośrodkach podejmowano próby rekonstrukcji czy odbudowy (np. Szczytnie i Reszlu). W innych zniszczona architekturę zastapiono blokami (Lidzbark Warmiński, Dobre Miasto). Po zakończeniu wojny wiele obiektów zabytkowych w różnym stopniu uległo przeobrażeniom8.

\section{Wyniki badań kolorystyki elewacji zabytkowych budynków z przełomu XIX i XX wieku Olsztyna i małych miast Warmii i Mazur}

W celu ustalenia pierwotnego wymalowania elewacji i ich stolarek otworowych budynków zastosowano następującą metodykę badawczą. Pierwszym krokiem było wykonanie odkrywek sondażowych, dzięki którym wytypowane zostały miejsca przeznaczone do dalszych analiz stratygraficznych. Pozwoliły one również na orientacyjne określenie stanu zachowania i charakter pierwotnych dekoracji. W celu ustalenia dokładnej stratygrafii z powyższych miejsc pobrano próbki, z których następnie wykonano naszlify?. Przekroje poprzeczne poddano obserwacji mikroskopowej w powiększeniu 100 i 200x, a następnie sfotografowano ${ }^{10}$. Na fotografiach oznaczono war-

7 M. Orłowicz, Ilustrowany przewodnik po mazurach Pruskich i Warmii, Olsztyn 1981, s. 70.

8 Ibidem, s. 9.

9 Próbki zatapiano w żywicy Duracryl O (producent Spofa Dental-Praha).

10 Fotografie przekrojów w świetle VIS oraz interpretację wyników badań wykonała autorka Ewa Doleżyńska-Sewerniak (zdjęcia wykonano przy użyciu aparatu cyfrowego Nikon D-70). Badania wykonano przy użyciu mikroskopu Optiphot 2 (powiększenia 100 i 200 x). 
stwy. Wykonano dokumentację fotograficzną i opisową przeprowadzonych badań. Miejsca wykonania odkrywek zaznaczono na fotografiach. Stratygrafię warstw pobranych próbek zestawiono w tabelach. Wyniki badań prowadzonych in situ konfrontowano ze źródłami historycznymi.

Nie we wszystkich budynkach rozpoznanie pierwotnego wymalowania było możliwe do ustalenia lub nie na wszystkich elementach elewacji. Analiza stratygraficzna nie daje zupełnej pewności dotyczącej pierwotnej proweniencji rozpoznanych warstw, ponieważ nie zawsze pierwsza zidentyfikowana polichromia jest oryginalna. Nie istnieje także doskonała metoda, która w sposób jednoznaczny wskazałaby na oryginalność odkrytych nawarstwień. Dlatego też badania takie dają duży margines dowolności. Ponadto analizy stratygraficzne prowadzone sa miejscowo, co może być przyczyną błędów interpretacyjnych. Lepsze rezultaty i weryfikacje wyników badań schodkowych w kilku przypadkach osiagano dopiero po usunięciu tynków i wymalowań wtórnych. W wielu obiektach rozpoznanie oryginalnych warstw komplikował fakt, że zachowane były one szczątkowo, pod wtórnymi wymalowaniami, miejscowymi przemurowaniami i reperacjami. W okresie tym w różny sposób opracowywano lica elewacji. Niekiedy całość tynków pokrywano jednolitym kolorem, następnie różnicowano barwnie detale. Innym razem takie rozróżnienie kolorystyczne następowało na początku prac malarskich. Utrudniało to określenie zachodzących relacji miedzy warstwami tynków i wymalowań.

Przeprowadzone badania wykazały, że elewacje tego regionu malowano najchętniej w różnych odcieniach ugru, beżu, różu, fioletu, brązu i szarości. Dotyczy to zarówno budynków Olsztyna, jak i małych miast Warmii i Mazur.

Spośród 15 zabytkowych budynków Olsztyna poddanych badaniom większość była tynkowana i barwiona na następujące kolory: écru, odcienie pomarańczowego, ugrowo-żółty, beżowo-ugrowy i ugrowy. Rzadziej identyfikowano odcienie szarości i błękitu. Elewację jednego budynku (4) ${ }^{11}$ w całości wymalowano pierwotnie w kolorze niebieskim. Gzymsy i ścianę fasady innej kamienicy (10) pokrywała szaroniebieska warstwa barwna,

11 Numery w nawiasach odnoszą się do numeracji elewacji w tabeli nr 1. 
w partii detali o nieco jaśniejszym odcieniu. W innym obiekcie (9) z kolei kolor szaroniebieski lica zestawiono z jasnobeżowymi gzymsami. W przypadku elewacji wymalowanych w słabszych lub intensywnych odcieniach ugru zaobserwowano zróżnicowanie kolorystyczne w obrębie detali i tła w trzech przypadkach $(11,13,15)$. Pozostałe barwione były jednolicie $(1,6,7,8,12,14)$. Trzy kamienice mają fasady łączące cegłę licówkę z tynkowanymi i malowanymi gzymsami $(3,5,13)$. W jednym z nich czerwona, ceglaną elewację udekorowano sztukateriami barwionymi na żółto i obramieniami okiennymi w kolorze écru oraz fioletowym, barwionym w masie spoinowaniem (3). W kamienicy przy ul. Żeromskiego 39 w Olsztynie opracowana w tynku partia cokołowa i detale połączono z czerwoną cegła ścian. Natomiast w obiekcie przy ul. Jagiellońskiej 50 w Olsztynie ceglany, czerwony cokół połączono z ugrowymi ścianami. W obu budynkach spoinowanie podbarwiono na kolor ugrowy, nawiązujacy do barwy lica lub detali.

Tynki analizowanych elewacji były zarówno zacierane na gładko, jak i fakturalne, najczęściej w postaci tzw. baranka, czyli nakrapiane. Częściej fakturę stosowano do wykończenia tła (4), rzadziej detali (np. 6). Jeszcze rzadziej stosowano tynki szlachetne - rowkowane (np. 9), boniowane $(1,3,8,10$ i 12) czy sztukaterie (np. 2 i 12). To samo dotyczy detali roślinnych i geometrycznych wykonanych w mokrym tynku, które występuja jedynie w dwóch spośród 15 zbadanych elewacji Olsztyna. Są to budynki przy ul. Zientary-Malewskiej 3 i Pl. Bema 3 w Olsztynie.

Analiza zabarwienia stolarki otworowej zbadanych kamienic Olsztyna wykazała, że odcienie ugru ścian łączono chętnie z zielenią okien i drzwi $(5,8)$ lub ciemniejszymi brązami $(3,11,14)$, rzadziej z kolorem niebieskim (15), ewentualnie z barwa jaśniejsza np. écru (1). Elewacje szare, szaroniebieskie uzupełniano stolarka w zbliżonym tonie (np. 9), w kolorze szarozielonym (np. 4) lub brązowym (np. 10).

Badania wymalowań elewacji zabytkowych budynków małych miast Warmii i Mazur z kolei dowiodły, że najczęściej barwiono je w odcieniach ugru, beżu, pomarańczu, brązu i żółcieni. Popularne były również szarości, błękity i fiolety. Rzadziej identyfikowano odcienie zieleni. Lica budynków na tym terenie malowano także w odcieniach bladego różu i koloru łososiowego, rzadko na ciemny kolor granatowy. 
Spośród analizowanych budynków 8 ma elewacje łączące partie wykończone cegłą licówką z tynkiem, występującym albo w obrębie ścian, albo detali. Tylko w jednym przypadku elewacja wykonana była z żółtej cegły (40). W tym przypadku żółty kolor cegieł zestawiono z fioletowymi tynkami. W innym przypadku w całości czerwona, ceglana elewacja dopełniona została szarym kolorem spoinowania ścian i cokołu kamiennego, a także różową barwą spoin gzymsu wieńczącego (21). W trzech innych fasadach czerwone cegły tła połączone zostały z gzymsami wymalowanymi w odcieniach écru, żółcieni i beżu (31, 35, 49). W dwóch innych kamienicach ceglany czerwony cokół i detale zestawiono ugrowymi lub pomarańczowymi tynkami. Były to budynki przy ul. Roosevelta 19 w Mragowie i ul. Lipowej $1 \mathrm{w}$ Bartoszycach. W pierwszym z nich spoinowanie cegieł zostało podbarwione na kolor ugrowy. W kamienicy przy ul. Jana III Sobieskiego 8 w Ostródzie występuje czerwony, ceglany cokół, który połączono z elewacją barwioną na beżowo. W budynku przy ul. Hożej 15 w Lidzbarku Warmińskim w partii cokołowej można zaobserwować połączenie szarego kamienia i czerwonej cegły, które zestawiono z fioletowym i ugrowym kolorem tynków i detali.

W fasadach tych zastosowano pewien schemat barwny, którym posługiwali się architekci, projektując kolorystykę budynków z czerwonej cegły licówki. Dotyczy on łączenia tego materiału z tynkami o ograniczonej gamie barwnej: ugru, beżu i pomarańczu. Stolarka tych budynków natomiast konweniuje albo z kolorem cegieł lub tynków. Okna wymalowane są najczęściej w odcieniach écru lub brązu $(31,52)$. Drzwi pokrywano brązowymi, beżowymi lub zielonymi wymalowaniami $(31,35,52)$. W przypadku kamienicy wykończonej żółtą cegła, mieszczącej się przy ul. Warszawskiej 53 w Mragowie, kolor jej stolarki okiennej jest integralny z fioletowa barwa tynków. Drzwi natomiast pierwotnie wymalowane były w odcieniach brązu.

$\mathrm{Na}$ jednolity kolor w obrębie ścian i detali wymalowanych było 13 elewacji $(20,22,24,26,28,30,43,50,51,54,57,58,59)$. Wśród zidentyfikowanych barw sa pomarańczowy, ugrowy, beżowy, odcienie żółtego, łososiowy, szarobłękitny, beżoworóżowy, jasnoróżowy, zielony i oliwkowy.

Cztery elewacje wymalowano jednolicie, ale z nieznacznie zróżnicowanym odcieniem w obrębie detali i ścian. Jedna w odcieniach jasnego brązu (18), inna ugru (33), kolejna w szarościach (36) i ostatnia w odcieniach be- 
żu (60). Niemal we wszystkich kamienicach detale były jaśniejsze, z wyjątkiem fasady budynku przy pl. Ratuszowym 1 w Górowie Iławeckim, której ściany zabarwione były na kolor jasnougrowy, a detale na ciemnougrowy.

Często w przypadku elewacji wymalowanych jednolicie lub z nieznacznie zróżnicowanymi gzymsami i tłem można zaobserwować także urozmaicenie opracowania powierzchni tynków, które w partii ścian były zazwyczaj fakturalne, a w obrębie detali gładkie (np. 29, 26, 30, 59).

Kolorystyka stolarki w tych monochromatycznych budynkach nawiazuje do barwy ich fasad. I tak np. odcienie brązu, ugru, beżu, żółcieni, koloru łososiowego zestawiano z oknami w kolorze écru (np. 18, 22, 28, 54), brązowym (43), ewentualnie białym (50, 59), rzadziej zielonym $(57,60,61)$. Elewacje pomarańczowe, beżowe, łososiowe uzupełniano brązowymi lub beżowymi drzwiami (np. 20, 28, 30, 59). Fasady wymalowane w odcieniach szarości często miały stolarkę kontrastującą w kolorze. I tak np. budynek przy ul. Ratuszowej 2 w Lidzbarku Warmińskim wypełniały okna w kolorze écru i brazowe drzwi. Budynek przy ul. Kresowej 2 w Biskupcu miały białe okna. Oliwkowe lico budynku przy ul. Mickiewicza 12 w Biskupcu uzupełniono ciemnozieloną stolarka.

W przypadku dużej grupy obiektów nie udało się rozpoznać kolorystyki wszystkich partii elewacji. Analiza zidentyfikowanych wymalowań tynków i stolarki daje orientacyjny obraz tendencji barwnych w nich zastosowanych. I tak np. budynek przy ul. Wysokiej Bramy 9 w Lidzbarku Warmińskim miał szare gzymsy oraz białe okna i niebieskie drzwi. Bonie dolnej kondygnacji budynku przy ul. Królewieckiej 7 w Mragowie były beżowe. W tym samym kolorze wymalowane były bonie jego wyższych pięter. Niestety, w tym przypadku nie udało się ustalić koloru tła budynku. Beżowa barwa detali została zestawiona z oknami w kolorze écru i brązowymi drzwiami. Kamienica przy ul. Krasickiego 3 w Górowie Iławeckim miała jasnobeżowe detale, a przy ul. Wyszyńskiego 18 gzyms w kolorze écru i brązowe drzwi. Gzymsy kamienicy przy ul. Kajki 2 w Lidzbarku Warmińskim były brązowe, a stolarka wymalowana w odcieniach zieleni.

Kilkanaście zbadanych elewacji małych miast Warmii i Mazur ma zróżnicowane kolory w obrębie ścian i detali. Wśród zestawień barwnych w nich występujących można zaobserwować pewne dominacje. W kilku przypadkach rozpoznano połączenia fioletu lub różu z ugrem, ewentualnie 
beżem i odcieniami écru (np. 16, 32, 38, 48). W kilku z nich barwna fasada miała białe detale. Np. w elewacji budynku mieszczącego się przy pl. Powstańców Warszawy $15 \mathrm{w}$ Kętrzynie brązowo różowe ściany zestawiono z białymi detalami oraz białą stolarką. Łososiowe tło ścian i białe gzymsy występują także w zabytkowej kamienicy przy ul. Kresowej $2 \mathrm{w}$ Lidzbarku Warmińskim. Zielone lico i białe detale rozpoznano w budynku mieszczącym się przy ul. Krzywej 4 również w Lidzbarku Warmińskim. Natomiast granatowe ściany z białymi gzymsami miała kamienica przy ul. Mickiewicza 15 w Lidzbarku Warmińskim. Ugrowy kolor tła i biały detali został zidentyfikowany w zabytkowym budynku przy ul. Kopernika 2 w tej samej miejscowości, a szare ściany i cokół z białymi detalami występują w kamienicy przy ul. Żeromskiego $2 \mathrm{w}$ Mragowie.

Różowobeżowe lico elewacji budynku przy ul. Żeromskiego $1 \mathrm{w}$ Mrągowie urozmaicono zielenią detali. Zielone tło kamienicy przy ul. Wyszyńskiego 17 w Lidzbarku Warmińskim zestawiono z brązowo czerwonym cokołem i pomarańczowymi detalami. Natomiast zielone ściany elewacji kamienicy mieszczącej się przy ul. Konstytucji 3 Maja 5 w Lidzbarku Warmińskim wzbogacono gzymsami w kolorze écru.

Chętnie stosowano także brązowe tło ścian z beżowymi detalami (np. 25). Spotyka się również ugrowe fasady z szarymi gzymsami $(41,53)$.

Kolorystyka stolarki otworowej tych kamienic nawiązuje zazwyczaj do któregoś z kolorów występujących albo w obrębie tła lub detali. Ściany elewacji w odcieniach ugru, brązu, beżu, fioletu uzupełniano jaśniejszą stolarką okienna, np. w kolorach żółcieni, bladego różu i bieli. Rzadziej stosowano ciemniejsze odcienie, np. szarości, brązu czy zieleni. Drzwi tych budynków są zazwyczaj brązowe lub integralne $\mathrm{w}$ kolorze $\mathrm{z}$ jedna $\mathrm{z}$ występujących na elewacji barw. Tam, gdzie detale są białe, stolarka również bywa biała.

Tynki tych barwnych elewacji w partiach ścian były zarówno fakturalne, głównie nakrapiane, a w partii detali gładkie (np. 17, 25, 53). Mogły być również gładkie na całej powierzchni fasad. Dodatkowe urozmaicenie fakturalne wprowadzały tynki boniowane $(18,20,24,25,30,32,34,35$, 40, 41, 46, 49, 51, 54). Lica kilku zabytków urozmaicają też sztukaterie (30, 34, 35). W kilku fasadach zaobserwowano również występowanie tynków barwionych w masie (np. 17, 18, 20, 26, 28, 36, 43, 45, 48, 50, 55, 61). Niektóre $z$ boni dodatkowo urozmaicano fakturą uzyskiwana albo poprzez 
„dziobanie” (54) lub „kształtowanie kielnią” (35, 51). W jednym przypadku nadano im fakturę poprzez wciśnięcie w świeżą zaprawę bryłek koksu i następnie pokrycie ich kolejną, cienką warstwą tynku, pozwalającą na zachowanie uzyskanych w ten sposób chropowatości (30).

Analizując elewacje zbadanych kamienic, można dopatrzeć się pewnych preferencji w doborze ich barwy w poszczególnych dziesięcioleciach. Szarości stosowano chętniej od lat 80. XIX wieku, na przełomie XIX i XX wieku pojawia się kolorystyka fioletowa, natomiast zielenie częściej występowały na początku XX wieku. Trzeba jednak podkreślić, że dominującymi kolorami stosowanymi w barwieniu fasad były ugry, beże, brązy, odcienie écru, żółcieni, fioletu i różu.

Istotne jest porównanie osiagniętych rezultatów z informacjami zawartymi w traktatach budowlanych z epoki, w których zawarte są wskazówki dotyczące zestawień kolorystycznych, jakimi sugerowano się lub posługiwano w projektowaniu barwy budynków, a szczególnie z traktatem „Der bürgerliche Baumeister” z 1790 roku wydany w Gotha autorstwa niemieckiego architekta, radcy książęcego Kammerkomissionsrat, Friedricha Christiana Schmidta. W publikacji tej autor zagadnieniom tym poświęcił cały rozdzial ${ }^{12}$.

Schmidt zalecał malowanie fasad w kolorach jasnych i bladych. Wymienił pigmenty i ich kombinacje i mieszaniny, jakie stosowano w tym czasie do barwienia elewacji i uzyskiwania poszczególnych barw. Istotnym elementem tego traktatu jest tablica barwna zawierająca kombinacje kolorystyczne stosowane do wymalowań poszczególnych partii budynków (fot. 13). Jest ona podzielona na 4 części odpowiadające poszczególnym partiom budynku - cokołowi i boniowaniu, tłu fasady (płaskim płaszczyznom), obramieniom okiennym, gzymsom i lizenom (wypukłościom). Zestawienia kolorystyczne proponowane przez tego architekta obowiązywały wielu budowniczych i architektów na terenie miast niemieckich i polskich (Toruń, Poznań, Wrocław i Szczecin) od końca XVIII do początku XX wieku. Zgodnie $z$ tym traktatem remontowano i remontuje się wiele kamienic w Niemczech, oraz w niektórych miastach Polski (Zgorzelec, Wrocław) ${ }^{13}$.

12 J. Miśkowiec, op. cit., s. 87.

13 Ibidem, s. 88. 
Porównując polichromie analizowanych elewacji ze wzornikiem Schmidta, należy stwierdzić występowanie analogii w niektórych przypadkach. I tak np. kolorystyka elewacji zabytkowego budynku przy ul. Knosały 7 w Olsztynie jest zbliżona do zestawień barwnych jego wzornika o nr 17 i 29. Pierwotne wymalowanie kamienicy przy ul. Żeromskiego $1 \mathrm{w}$ Mragowie odpowiada zestawom barwnym Schmidta o nr 14, 22 i 27. Polichromia budynku przy ul. Wyszyńskiego $17 \mathrm{w}$ Lidzbarku Warmińskim przypomina zestawienie nr 31, przy ul. Powstańców Warszawy 15 w Kętrzynie i przy ul. Kresowej 2 w Lidzbarku Warmińskim kombinację nr 23. Z kolei barwy lica kamienic przy ul. Wyszyńskiego 20 w Lidzbarku Warmińskim, przy pl. Ratuszowym 14 w Górowie Iławeckim i przy pl. Jedności Narodowej w Jezioranach nawiązują do nr 25. Zestawienie nr 31 przypomina kolorystyka budynku przy ul. Konstytucji 3 Maja 5 w Lidzbarku Warmińskim, nr 9 fasada kamienicy przy ul. Krzywej 4 w tej samej miejscowości. Pierwotna polichromia zabytkowego budynku przy ul. Mickiewicza 15 w Lidzbarku Warmińskim dokładnie odpowiada nr 30 wzornika tego architekta. Numerowi 11 z kolei wymalowanie kamienicy przy ul. Kopernika 2 w Lidzbarku Warmińskim. Zbliżona do nr 12 jest kolorystyka budynku przy pl. Młyńskim 4 w Lidzbarku Warmińskim, a do nr 30 polichromia obiektu przy ul. Żeromskiego $2 \mathrm{w}$ Mragowie.

Większość badanych elewacji ma zniszczone odspajające się tynki. Część z nich jest odrapana. Ich gzymsy i detale są uszkodzone. Budynki szpeca często graffiti, współczesne reklamy, szyldy, skrzynki i kable od instalacji gazowych i elektrycznych. Wiele z nich ma wymienioną stolarkę na współczesną. Większość pokrywaja tynki i wymalowania wtórne. Analizując jednak ich współczesną kolorystykę, należy stwierdzić, że w nielicznych przypadkach jest ona taka sama lub zbliżona do oryginalnej. W dziesięciu elewacjach jeden z kolorów nawiązuje do barwy historycznej któregoś z elementów fasad (1, 9, 16, 29, 33, 48, 49, 55, 56, 61). Tylko w kamienicy przy ul. Jagiellońskiej $50 \mathrm{w}$ Olsztynie jest on dokładnie taki sam jak pierwotny. 


\section{Podsumowanie}

Podsumowując przeprowadzone badania, należy stwierdzić, że zidentyfikowanie ugru, żółcieni, pomarańczu, beżu, różu, fioletu, brązu, szarości i błękitu jako najczęściej występujących kolorów tynków elewacji Olsztyna i małych miast Warmii i Mazur jest zgodne z ogólnymi ówczesnymi tendencjami w barwieniu fasad zabytkowych budynków. Wąska gama kolorów wynika z dużej trwałości i dostępności żelazowych pigmentów takich jak ugry, brązy, czerwienie żelazowe i czernie roślinne, które były podstawowymi wypełniaczami farb lub barwionych tynków, za pomocą których uzyskiwano wyżej wymienione kolory ${ }^{14}$.

Zaobserwowanie pewnych preferencji $\mathrm{w}$ doborze barwy elewacji w poszczególnych dziesięcioleciach analizowanego okresu może być pomocne w rekonstruowaniu polichromii tynków tych kamienic, których pierwotne wymalowania nie zachowały się. Natomiast popularność niektórych zestawień barwnych w obrębie fasad i stolarek otworowych świadczyć może o istnieniu mód na konkretne kolory i ich połączenia, jakie występowały w tym regionie. Dotyczy to popularnych połączeń fioletu lub różu z ugrem, ewentualnie beżem i odcieniami écru w budynkach w całości tynkowanych, a w przypadku obiektów łączących partie tynkowane i cegłę zestawień tego materiału z ugrowymi, beżowymi i pomarańczowymi tynkami.

Istotne dla praktyki konserwatorskiej jest zaobserwowanie analogii wymalowań niektórych fasad z projektami Schmidta, co może świadczyć, że jego traktat mógł być znany na tym terenie. Fakt ten może zostać wykorzystany w sytuacjach, gdy trudne jest zidentyfikowanie kolorystyki całej elewacji. Na podstawie wzornika tego architekta możliwa jest rekonstrukcja nierozpoznanej barwy fragmentu budynku. Nie można także wykluczyć, że zestawienia kolorystyczne zawarte w jego publikacji zostały spopularyzowane na tym obszarze w inny sposób lub że były po prostu popularne w tym czasie.

14 I. Płuska, Zabytkowe tynki - aspekt techniczny i estetyczny, w: Kolorystyka zabytkowych elewagi od średniowiecz̧a do wspótczesności..., s. 301. 
Badania kolorystyki fasad zabytków Olsztyna i małych miast Warmii i Mazur z przełomu XIX i XX wieku nie tylko dokumentuja pozostałości pierwotnych narzutów i wymalowań, które często w trakcie remontów są usuwane. Są one niezbędne w przywracaniu autentycznego wyglądu historycznym obiektom.

\section{Summary}

\section{Colour schemes of the facades of historical buildings within the area of Olsztyn and small towns of Warmia and Masuria at the turn of the 20th c.}

The article presents the results of several years of studies of colour schemes of historical building facades within the area of Olsztyn and small Warmia and Masuria towns, carried out by the author of this publication between 2007 and 2011. The reason for undertaking the studies are extensive repairs and building works, resulting in removal of often damaged historical plasters, as well as loss of the authentic appearance of historic buildings.

The analysis showed that the majority of the facades in the area were painted in different shades of yellow, orange, beige, pink, violet, brown, grey and blue. Less often were recognized shades of green. Shades of grey were applied more from the eighties of 18th century. At the turn of the 20th century the facades could have violet colour. Shades of green were applied more often at the beginning of the 20th century.

Many of the buildings covered originally uniform colour within all parts of the facade. Sometimes colored facades had slightly lighter or white painted cornices. A large group of the facades had a varied colors within the walls and details. Among the colorful statements in them that can be observed some domination. In a few cases there were recognised connections of violet or pink with ochre or beige and ecru shades. In the case of the buildings merging parties plastered and bricked can be seen a colour scheme, which used architects designing their facades. It refers to the statements of the brick and the plaster with a limited range of colour range: ochre, beige and orange.

The analysis provides information on fashion and trends popular in the area in colouring of the facades of historic buildings at the turn of the 20th century on the territory of the present province of Warmia and Mazury Conducted researches can be used as a basis for reconstruction and recreation of polichromy historic buildings in the area. 


\section{Aneks}

Tabela 1. Kolorystyka zabytkowych budynków Olsztyna i małych miast Warmii i Mazur na przełomie XIX i XX wieku

\begin{tabular}{|c|c|c|c|c|c|c|c|c|c|c|}
\hline \multirow{3}{*}{$\mathrm{vi}$} & \multirow{3}{*}{ Lakalieanjy } & \multirow{3}{*}{$\begin{array}{c}\text { Cen } \\
\text { ponutaria }\end{array}$} & \multicolumn{6}{|c|}{ Koter we NCSe } & \multicolumn{2}{|c|}{ 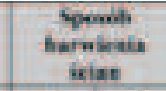 } \\
\hline & & & \multirow{2}{*}{ 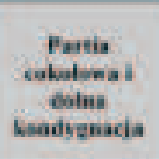 } & \multirow[b]{2}{*}{ Selany } & \multicolumn{2}{|c|}{ Betalr } & \multirow[b]{2}{*}{ Okn } & \multirow[b]{2}{*}{ Drroi } & \multirow{2}{*}{$\frac{1}{1}$} & \multirow{2}{*}{$\frac{f_{i}}{\frac{1}{2}}$} \\
\hline & & & & & 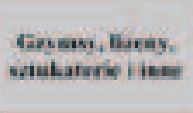 & 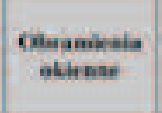 & & & & \\
\hline \multicolumn{11}{|c|}{ iasit } \\
\hline 1 & 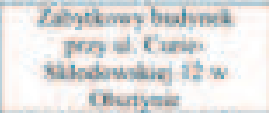 & 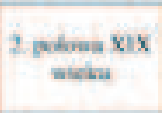 & \multicolumn{4}{|c|}{ 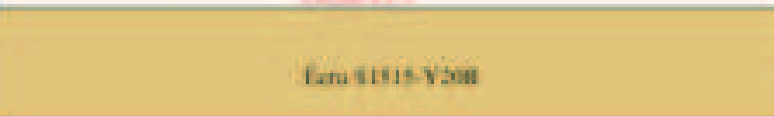 } & $\begin{array}{l}\text { Gine } \\
\text { sineser }\end{array}$ & $\lim _{\sin 202}$ & " & * \\
\hline 2 & 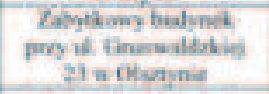 & $\begin{array}{c}\text { Kenews XIX } \\
\text { misdar }\end{array}$ & \multicolumn{4}{|c|}{$y$} & Wialy & 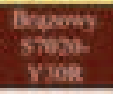 & 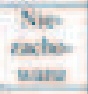 & $\begin{array}{l}\text { Noe } \\
\text { ache } \\
\text { sones }\end{array}$ \\
\hline \multirow[b]{2}{*}{3} & Reyaswory butines & \multirow{2}{*}{$\begin{array}{l}\text { Kenis } x u x \\
\text { mode }\end{array}$} & Sase & now cesta & \multirow{2}{*}{$\begin{array}{l}\text { Suak-nith } \\
\text { sieve-yaie }\end{array}$} & \multirow{2}{*}{$\begin{array}{l}\text { Jaby dive } \\
\text { sises-visen }\end{array}$} & & \multirow[b]{2}{*}{$=$} & \multirow[b]{2}{*}{ t } & \multirow[b]{2}{*}{ - } \\
\hline & $\begin{array}{l}\text { pory Linia } 5= \\
\text { Owatyais }\end{array}$ & & $\begin{array}{l}\text { Talsin: } \\
\text { ini }\end{array}$ & 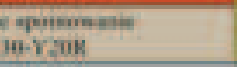 & & & $\begin{array}{l}\text { Sest: } \\
\text { Yloe }\end{array}$ & & & \\
\hline * & 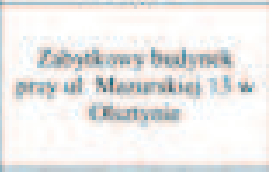 & 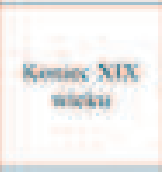 & \multicolumn{4}{|c|}{ 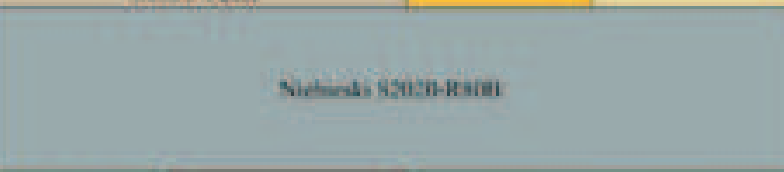 } & 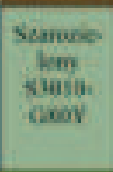 & 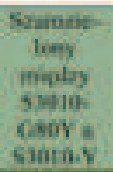 & , & $F$ \\
\hline \multirow[b]{2}{*}{$\$$} & \multirow{2}{*}{ 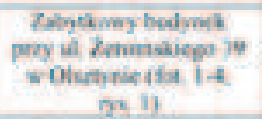 } & \multirow{2}{*}{$\begin{array}{l}\operatorname{xix} x x \\
\text { mexte }\end{array}$} & \multirow{2}{*}{ 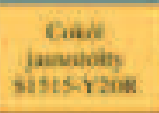 } & Cremantia cegle. & \multirow{2}{*}{\multicolumn{2}{|c|}{ Amonaty s1915-yzui }} & \multirow{2}{*}{$\begin{array}{l}\text { Relowy } \\
\text { stopos } \\
\text { cisor }\end{array}$} & \multirow{2}{*}{$\frac{\sin }{\sin x}$} & \multirow[b]{2}{*}{, } & \multirow[b]{2}{*}{$=$} \\
\hline & & & & 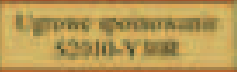 & & & & & & \\
\hline 6 & 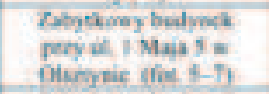 & $\begin{array}{c}\text { Lats } \\
\text { inve-iass }\end{array}$ & \multicolumn{4}{|c|}{$\begin{array}{l}\text { Mensaksausy } \\
\text { Szota-Yiog }\end{array}$} & - & - & - & " \\
\hline 7 & 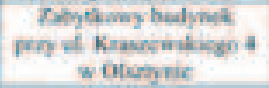 & $\begin{array}{l}\text { Poxipat } x x \\
\text { midue ef }\end{array}$ & \multicolumn{4}{|c|}{ 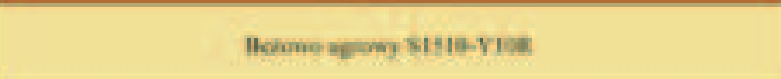 } & $=$ & $=$ & e & 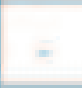 \\
\hline
\end{tabular}

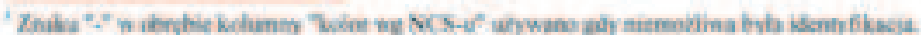




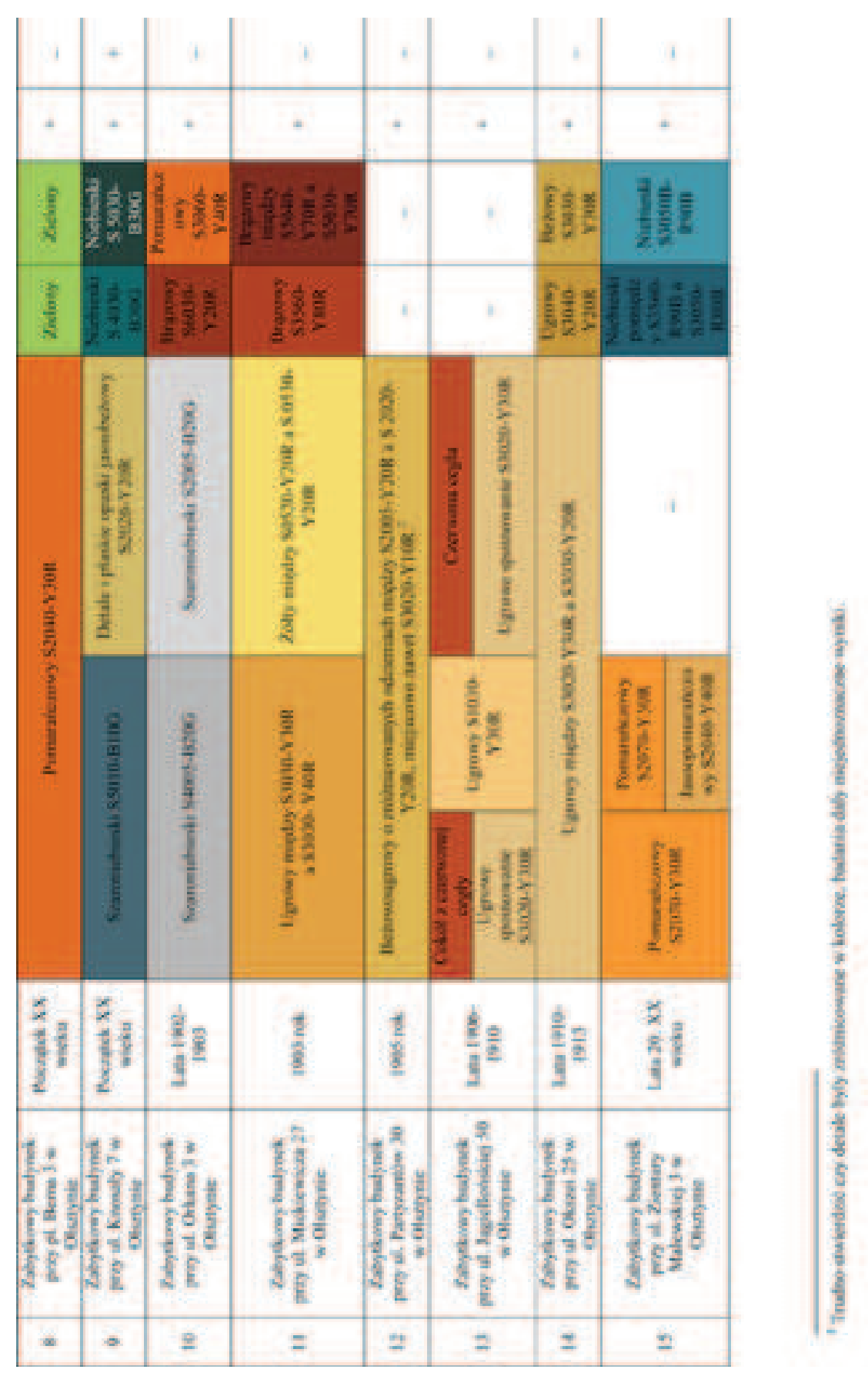




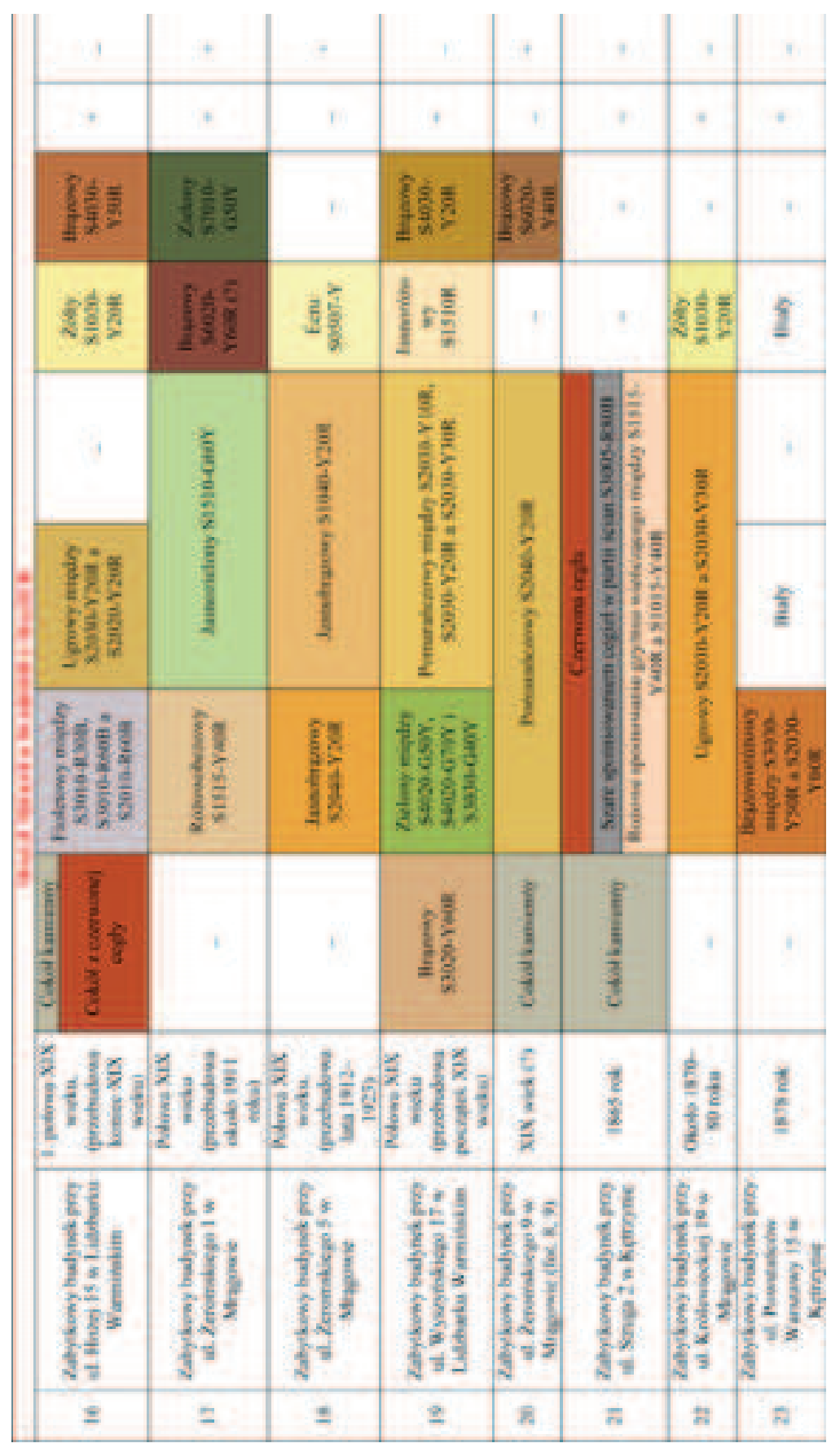




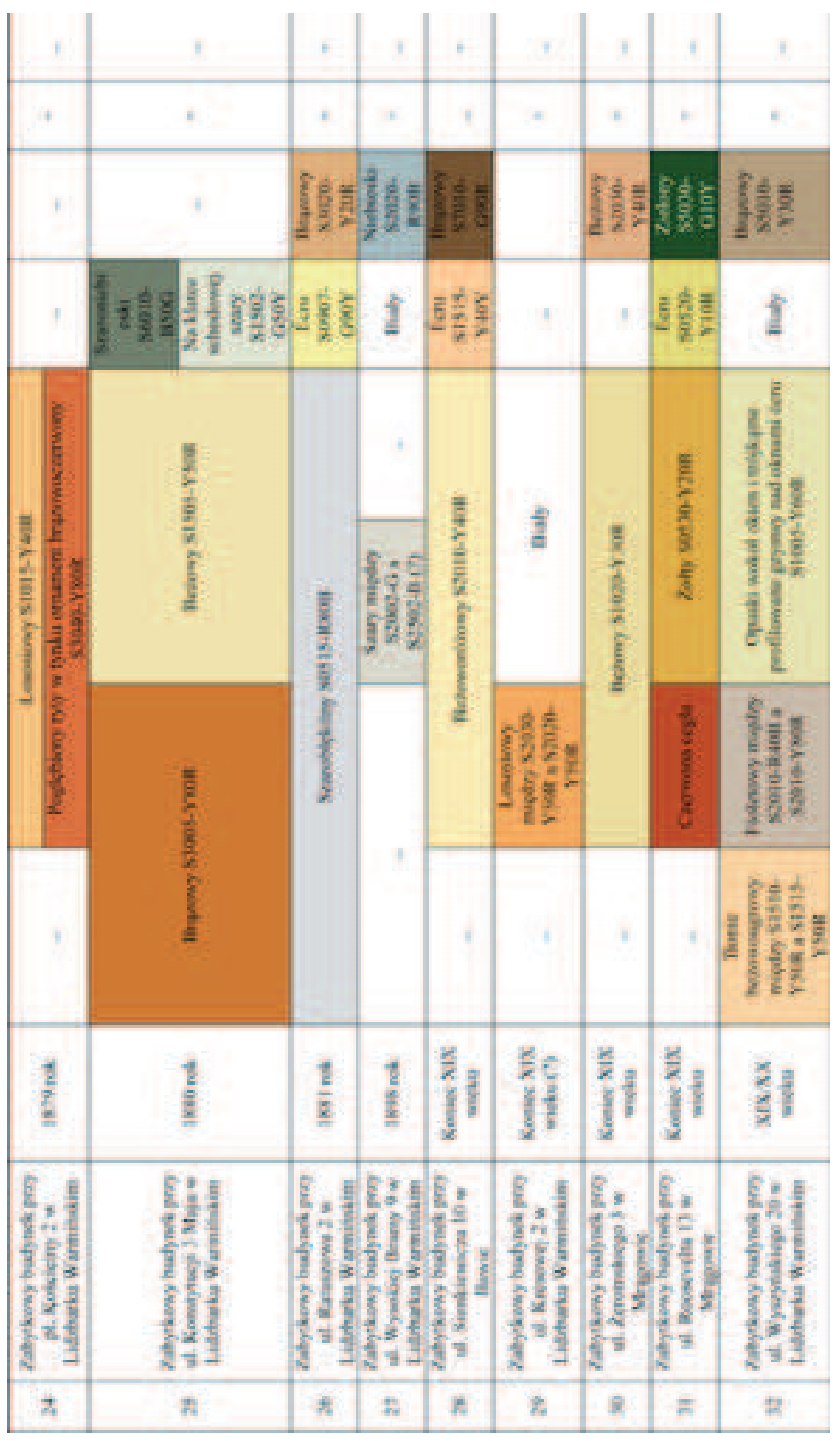




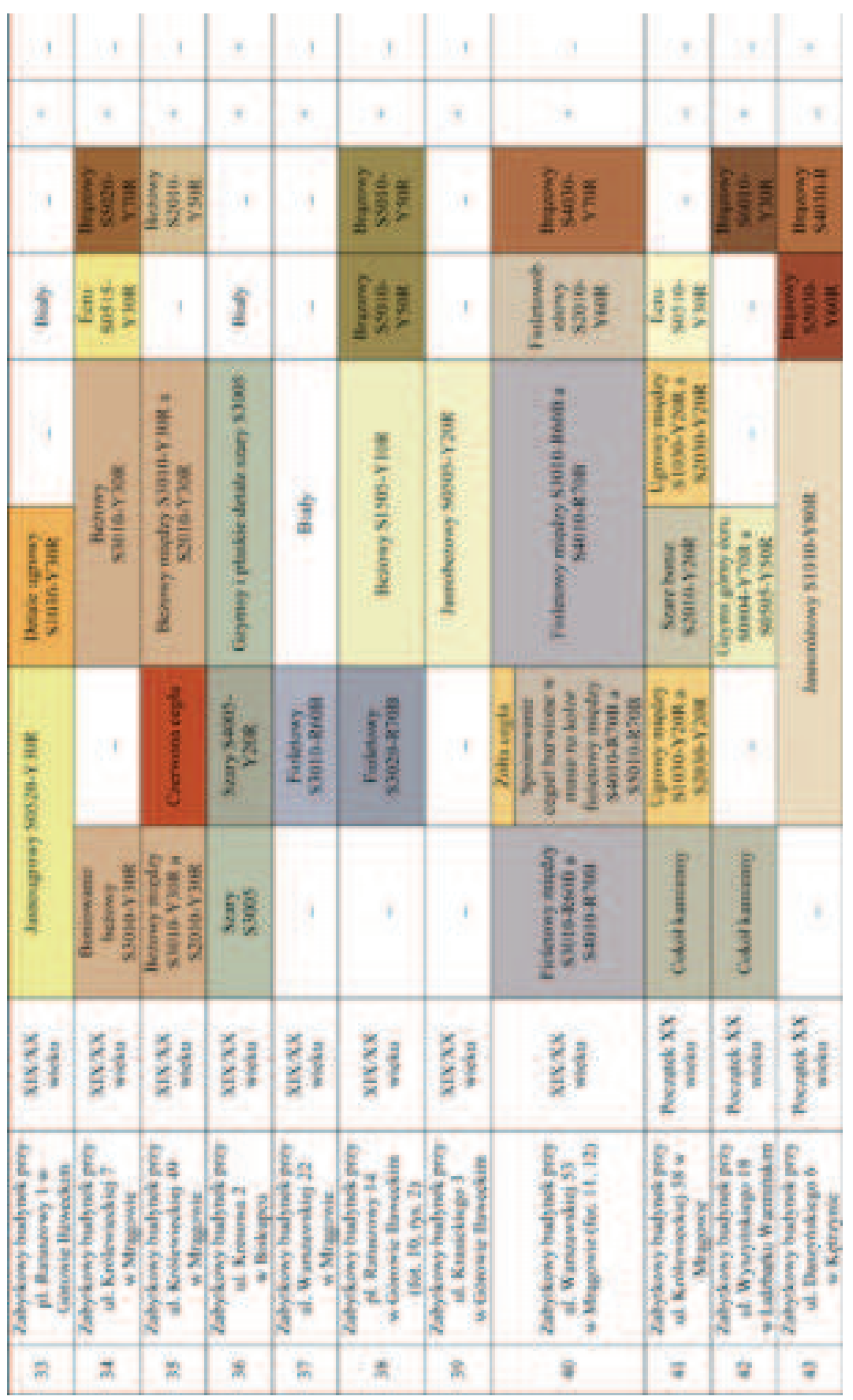




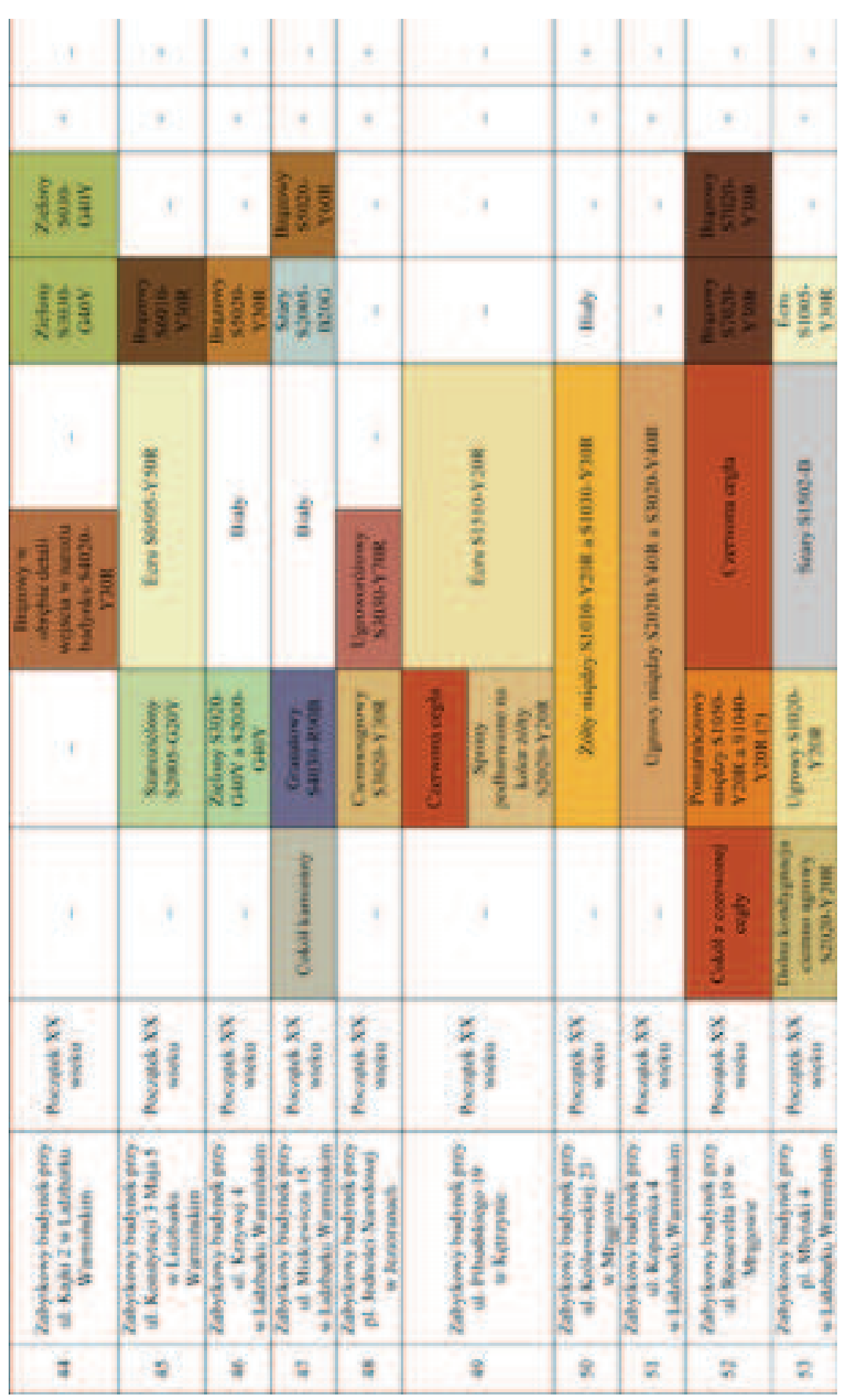




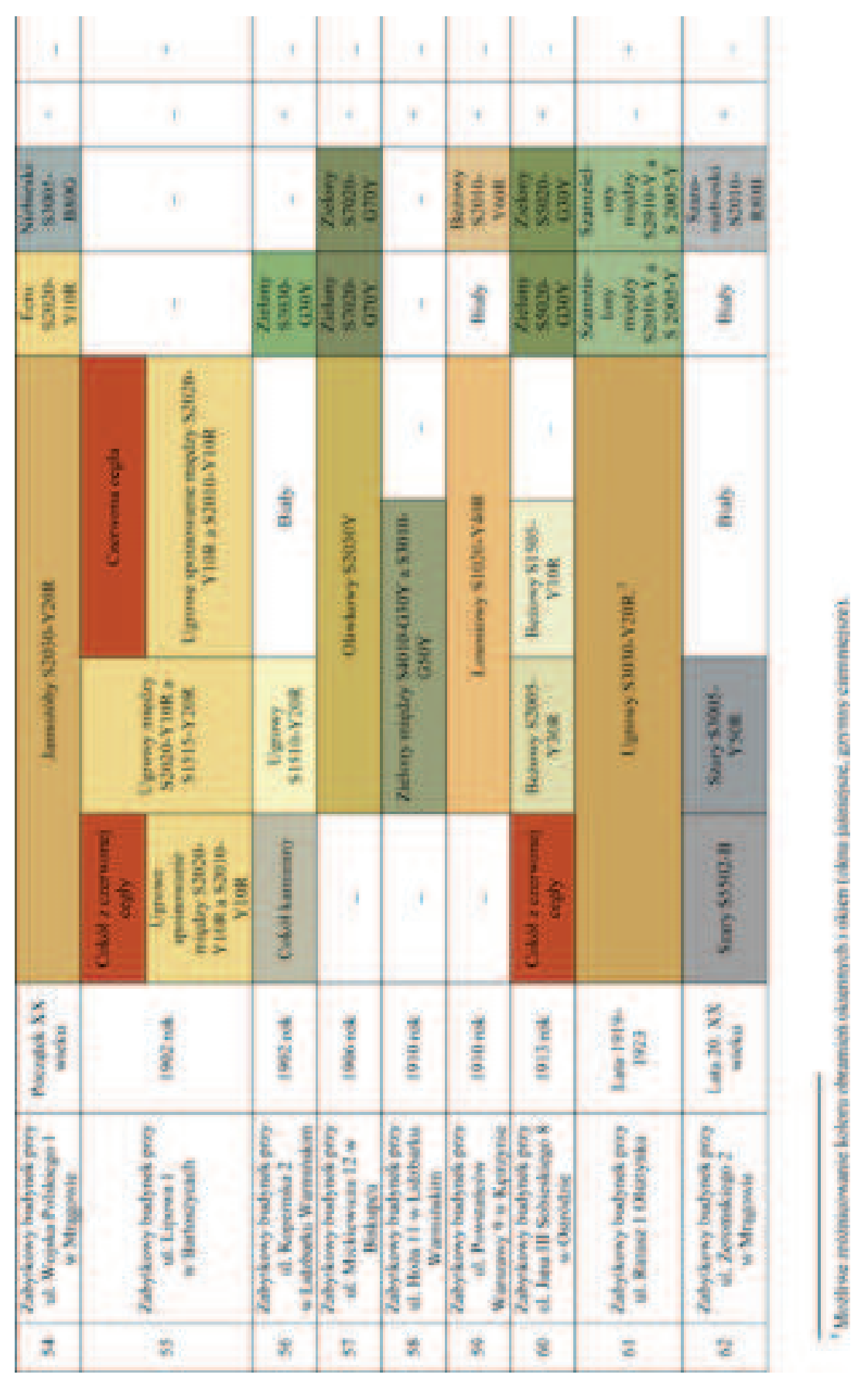




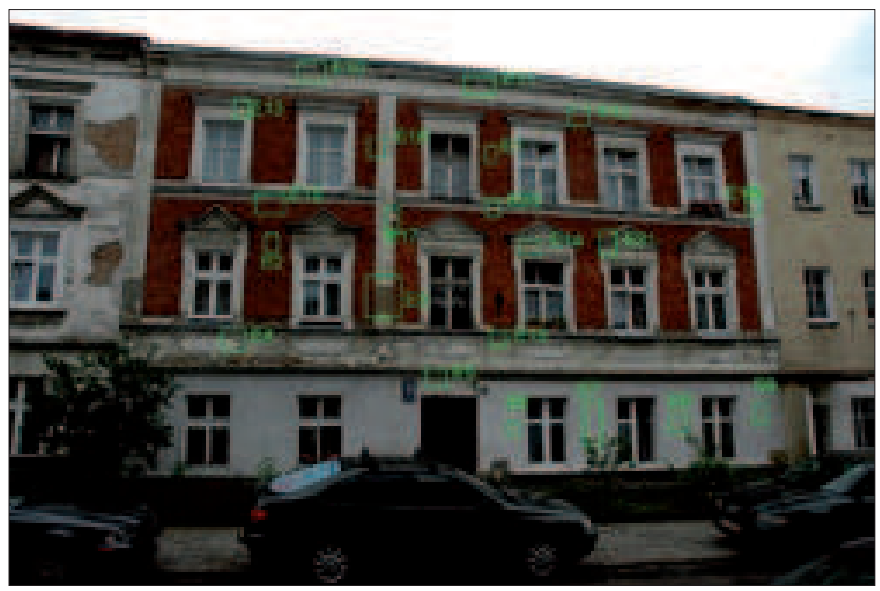

Il. 1. Widok elewacji frontowej zabytkowego budynku przy ul. Żeromskiego 39 w Olsztynie z zaznaczeniem miejsc wykonania badań (fot. E. Doleżyńska-Sewerniak)
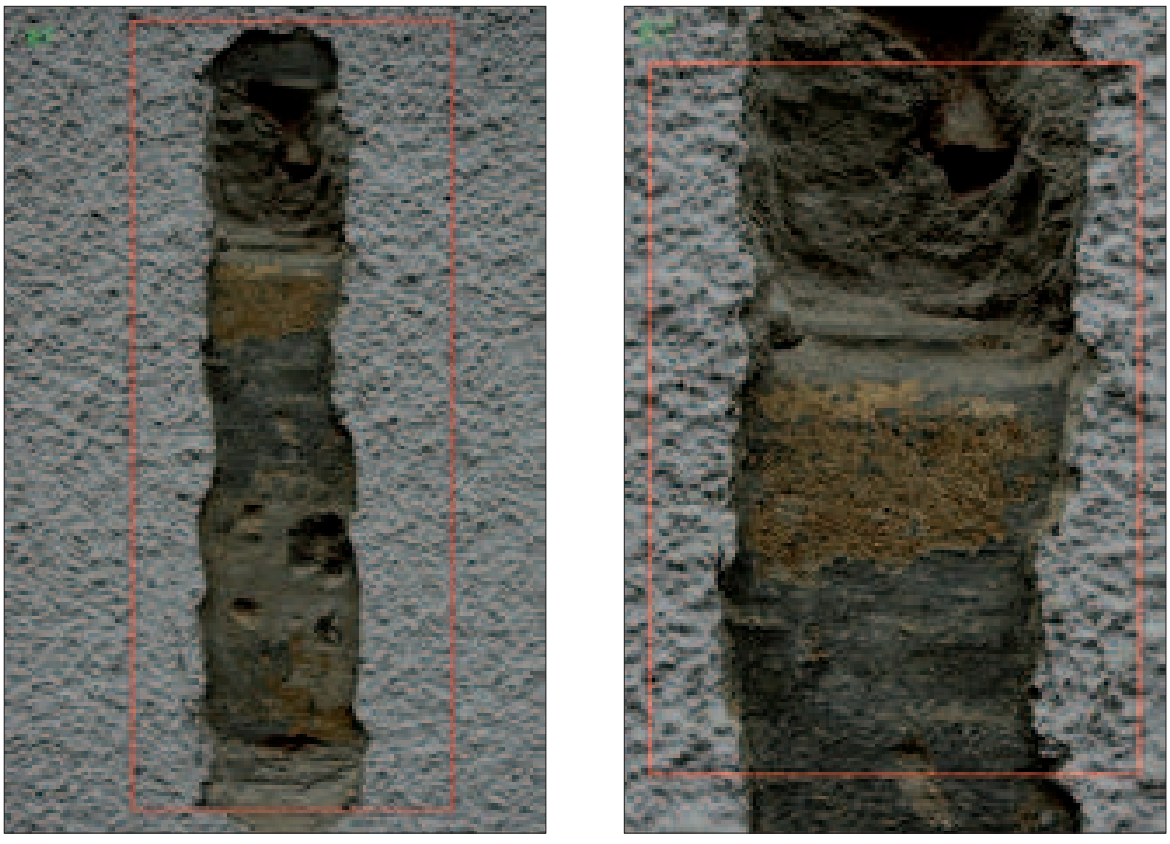

Il. 2 i 3. Widok i zbliżenie odkrywki E7 na elewacji zabytkowego budynku przy ul. Żeromskiego 39 w Olsztynie. Widoczne zatynkowane bonie w obrębie parteru budynku i ich pierwotne wymalowanie w kolorze jasnożółtym wg NCS-u S 1515-Y20R (fot. E. Doleżyńska-Sewerniak) 


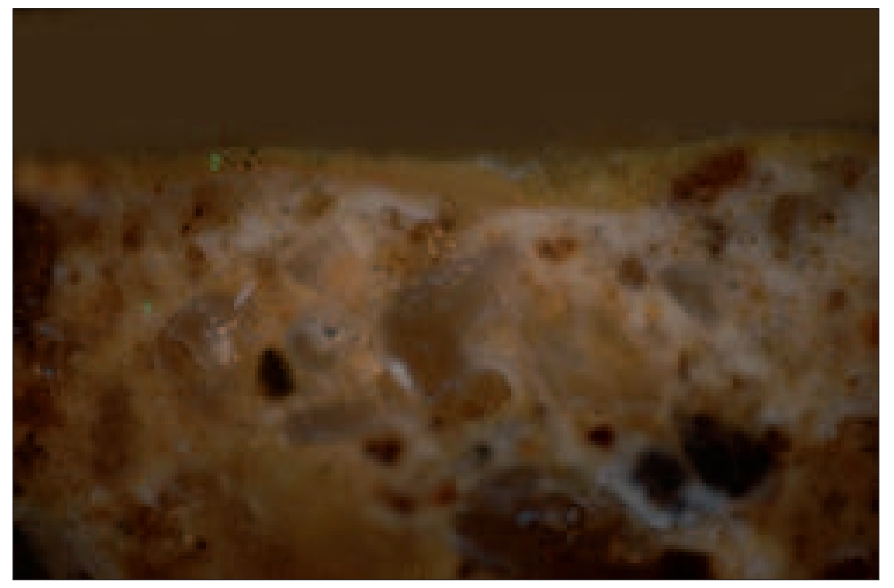

Il. 4. Widok przekroju nr 1 z odkrywki E5

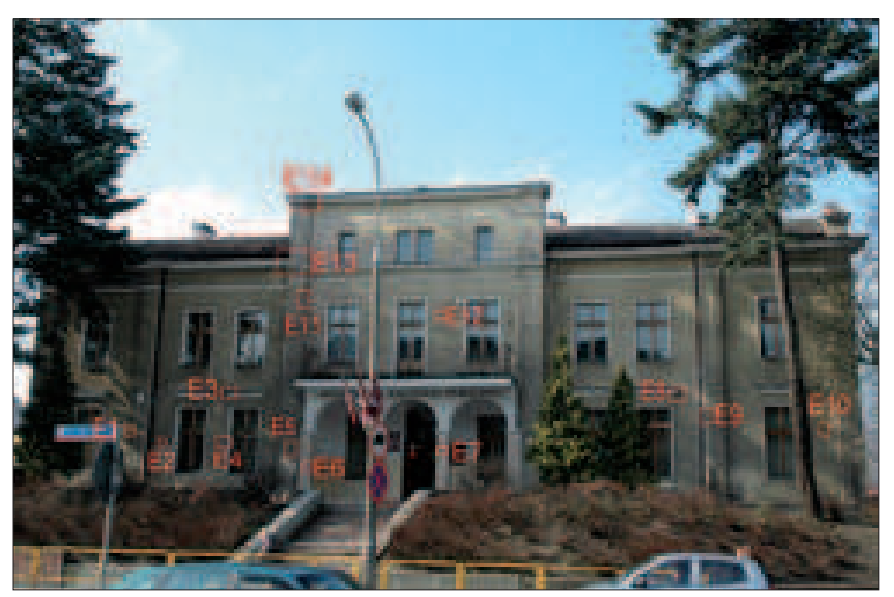

Il. 5. Widok elewacji frontowej zabytkowego budynku przy ul. 1 Maja 5 w Olsztynie z zaznaczeniem miejsc wykonania badań (fot. E. Doleżyńska-Sewerniak) 


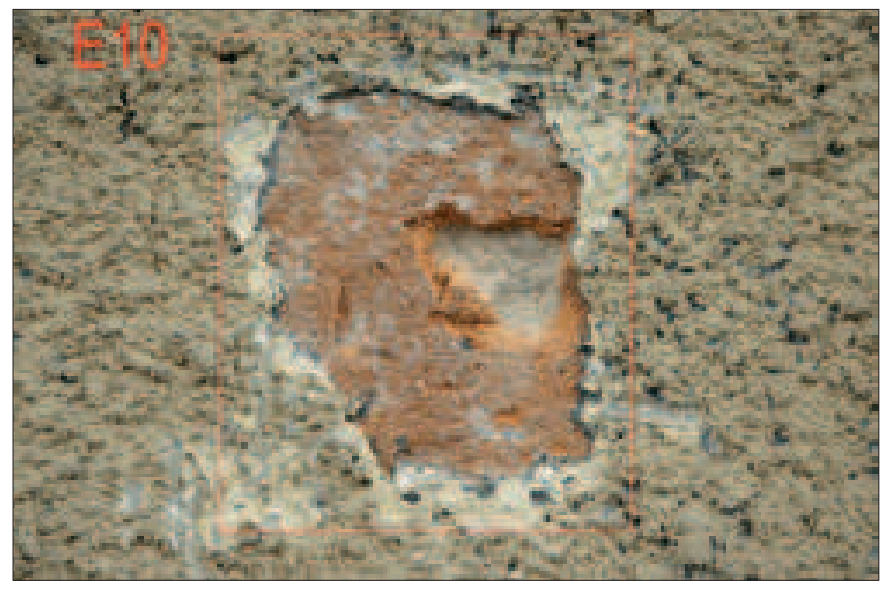

Il. 6. Widok odkrywki E10 na elewacji zabytkowego budynku przy ul. 1 Maja 5 w Olsztynie. Widoczne gładkie oryginalne tynki barwione w masie na kolor pomarańczowy wg NCS-u S 2040-Y30R (fot. E. Doleżyńska-Sewerniak)

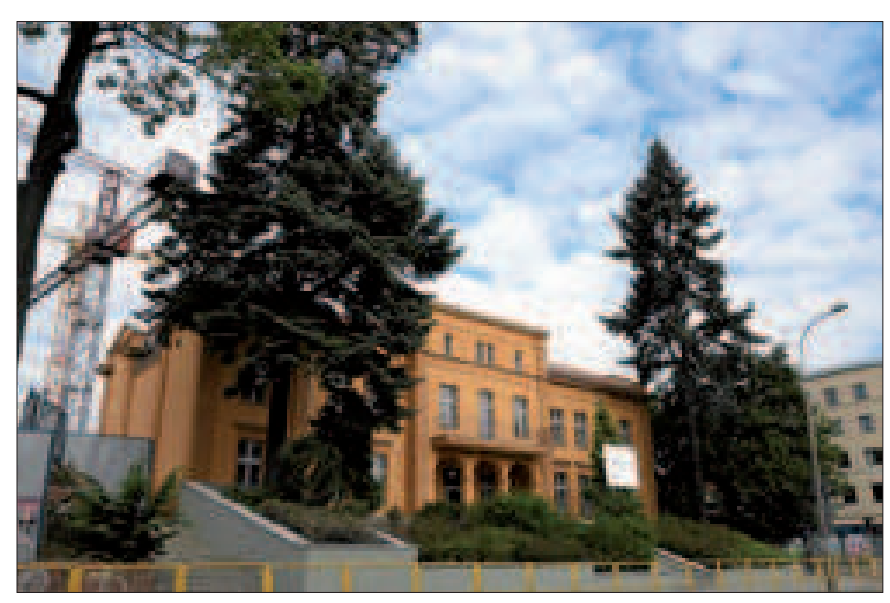

Il. 7. Widok elewacji frontowej zabytkowego budynku przy ul. 1 Maja 5 w Olsztynie po przywróceniu pierwotnej barwy (źródło: Internet) 


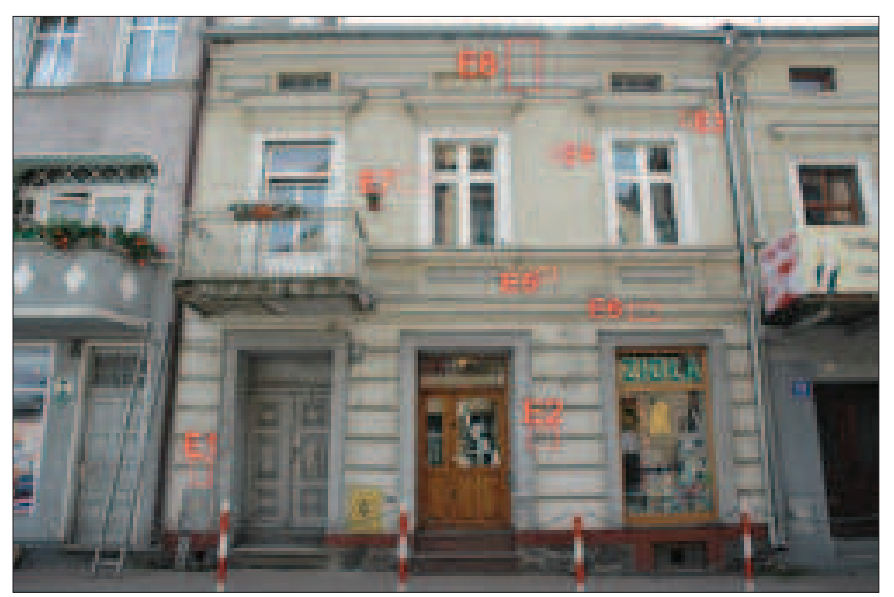

Il. 8. Widok elewacji frontowej zabytkowego budynku przy ul. Żeromskiego $9 \mathrm{w}$ Mrągowie z zaznaczeniem miejsc wykonania badań (fot. E. Doleżyńska-Sewerniak)

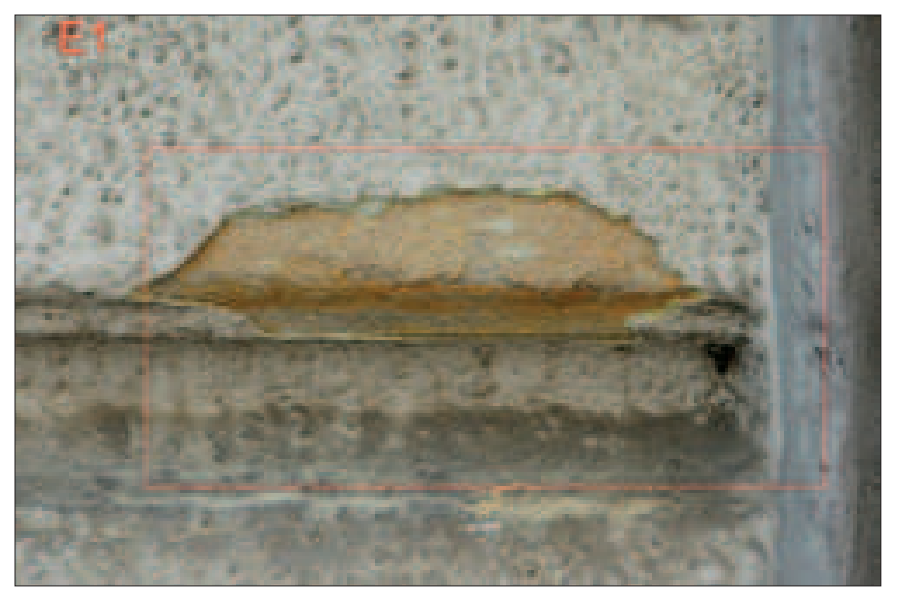

Il. 9. Widok odkrywki E1 na elewacji zabytkowego budynku przy ul. Żeromskiego $9 \mathrm{w}$ Mragowie. Widoczne oryginalne tynki barwione w masie na kolor pomarańczowy - wg NCS-u S 2040-Y20R (fot. E. Doleżyńska-Sewerniak) 
[375]

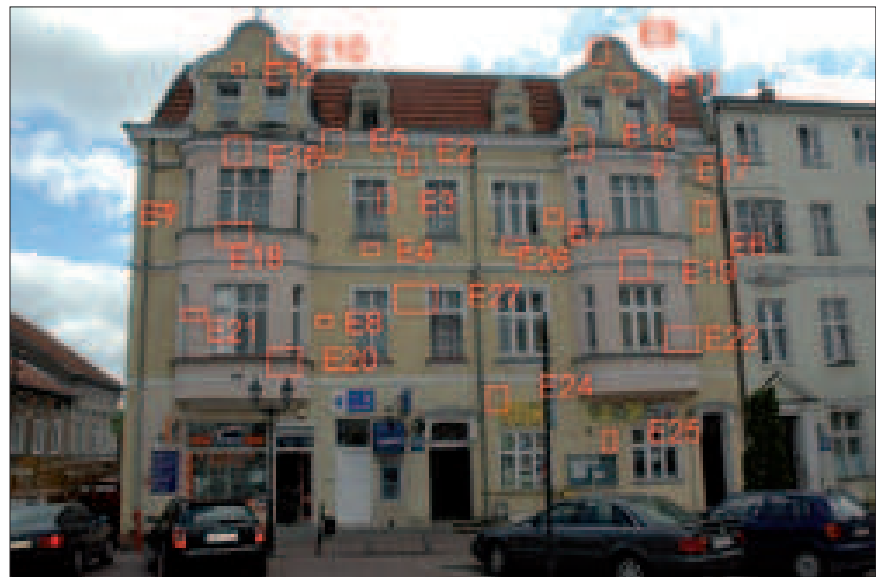

Il. 10. Widok elewacji frontowej zabytkowego budynku przy pl. Ratuszowym 14 w Górowie Iławeckim z zaznaczeniem miejsc wykonania badań (fot. E. Doleżyńska-Sewerniak) 


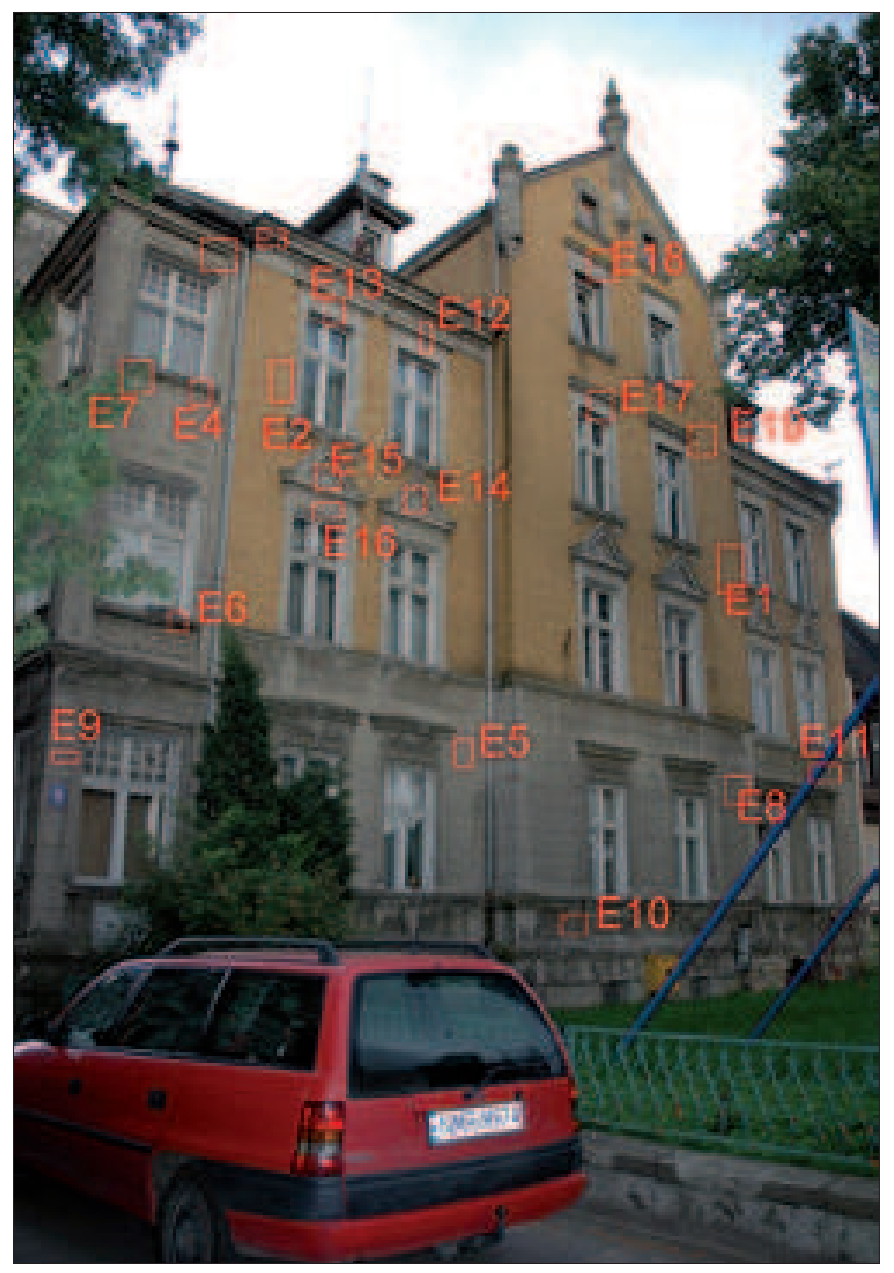

Il. 11. Widok elewacji frontowej zabytkowego budynku przy ul. Warszawskiej 53 w Mrągowie z zaznaczeniem miejsc wykonania badań (fot. E. Doleżyńska-Sewerniak) 


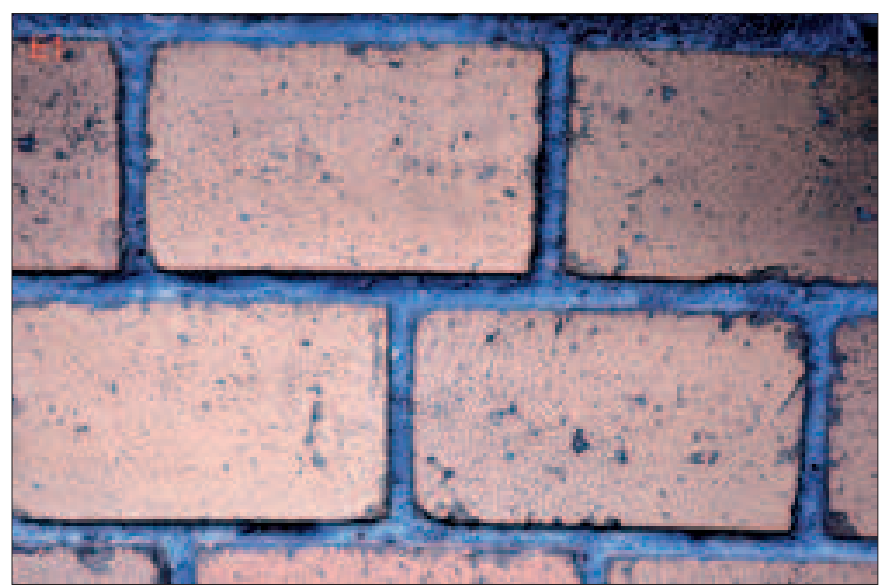

Il. 12. Widok odkrywki E1 na elewacji zabytkowego budynku przy ul. Warszawskiej 53 w Mragowie. Widoczne barwione w masie na kolor fioletowy spoiny cegieł wg NCS-u między S 4010-R70B a S 5010-R70B (fot. E. Doleżyńska-Sewerniak)

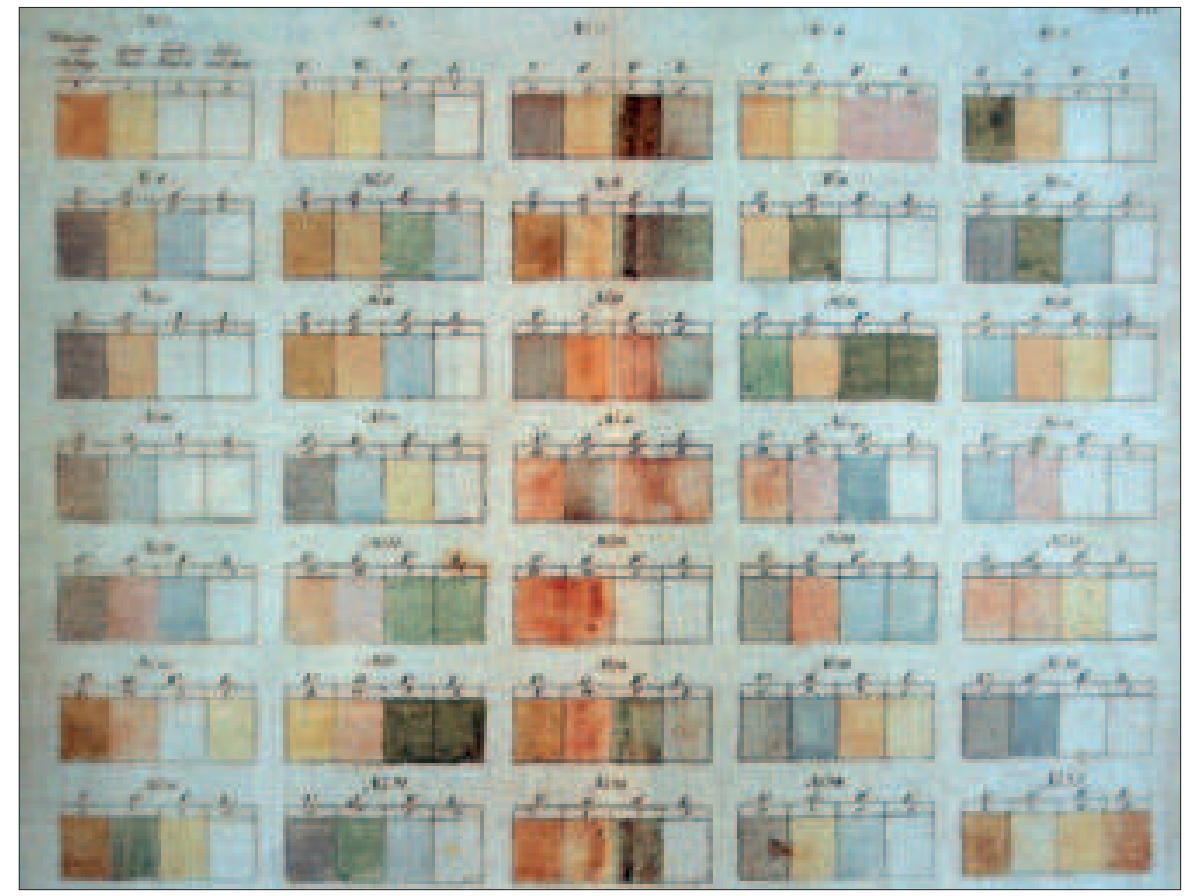

Il. 13. Tablica barwna z traktatu F. Ch. Schmidta „Der bürgerliche Baumeister” Gotha 1790 rok (w: Korzeniowski red., 2000) 


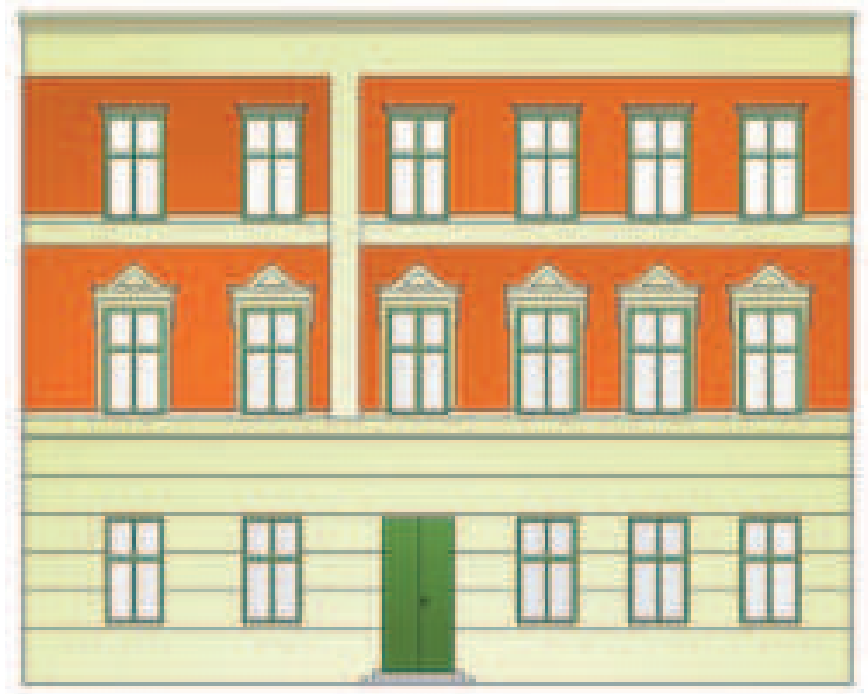

Rys. 1. Rekonstrukcja kolorystyki elewacji zabytkowego budynku przy ul. Żeromskiego 39 w Olsztynie (wyk. M. Sewerniak)

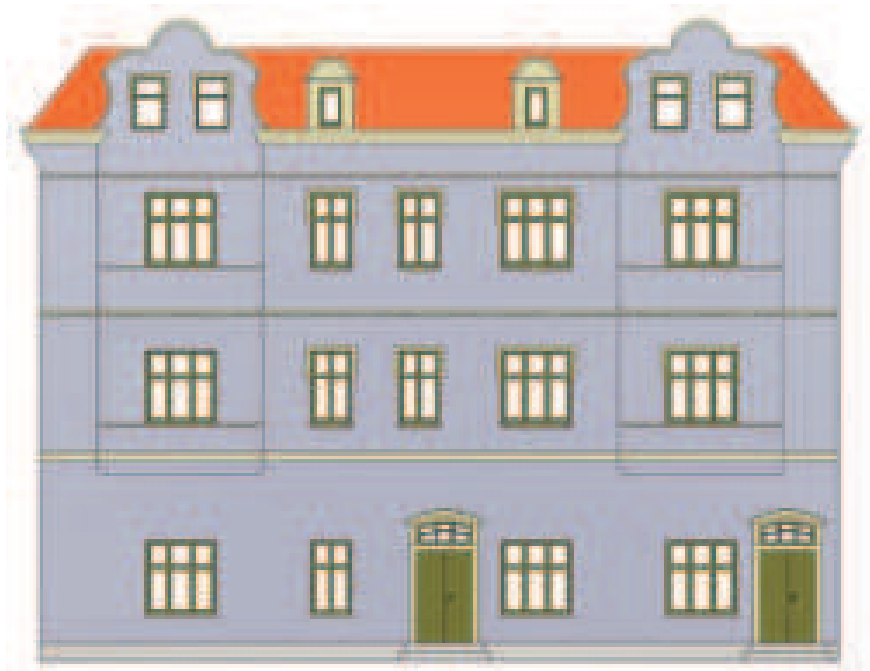

Rys. 2. Rekonstrukcja kolorystyki zabytkowego budynku przy pl. Ratuszowym 14 w Górowie Iławeckim (wyk. M. Sewerniak). 